\title{
DESIGN OF A SAFER LITHIUM COIN CELL BATTERY
}

doi:10.1136/injuryprev-2012-040580c.25

${ }^{1} \mathrm{~J} 0 \mathrm{k}^{*},{ }^{1} \mathrm{~A}$ Zwaan, ${ }^{2} \mathrm{P}$ Cooper. ${ }^{1}$ Victoria University of Wellington, New Zealand;

${ }^{2}$ Energizer Battery Manufacturing, USA

Background Ingestion of a lithium coin cell battery can result in serious injuries and the incidents are on the rise. Small size and coinlike appearance of the batteries make it very difficult to be aware of the ingestion promptly, which hinders a timely medical treatment.

Aims/Objectives/Purpose To cope with the growing health threat this research focuses on responsive polymer materials and reactive structure of coin cell batteries through an interdisciplinary approach of industrial design and chemical engineering.

Methods We designed a safer lithium coin cell battery to discourage swallowing and, even if ingested, provide a visible alarm instantly to nearby caregivers. In addition, the battery may remain inactive in an alimentary canal to minimise the likelihood of injuries associated with the ingestion.

Results/Outcome In simulation experiments, our prototypes emitted an easily noticeable warning immediately after ingestion and remained inert for more than $8 \mathrm{~h}$, showing a stark contrast to untreated batteries that caused a $\mathrm{pH}$ spike. The result suggests that the safety features may help an ingested battery be evacuated safely without inflicting injury on the body.

Significance/Contribution to the Field Our design may contribute to decreasing the ingestion cases and their consequent injuries through industrial application. 